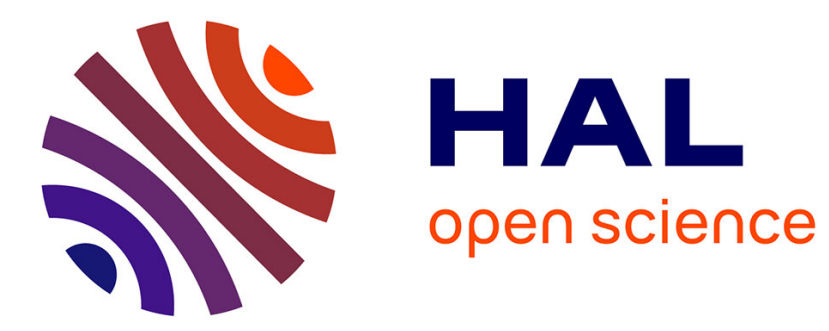

\title{
The impact of english dominance on literature and welfare
}

\author{
Jacques Mélitz
}

\section{To cite this version:}

Jacques Mélitz. The impact of english dominance on literature and welfare. Journal of Economic Behavior and Organization, 2007, 64 (2), pp.193. 10.1016/j.jebo.2006.10.003 . hal-00531868

\section{HAL Id: hal-00531868 \\ https://hal.science/hal-00531868}

Submitted on 4 Nov 2010

HAL is a multi-disciplinary open access archive for the deposit and dissemination of scientific research documents, whether they are published or not. The documents may come from teaching and research institutions in France or abroad, or from public or private research centers.
L'archive ouverte pluridisciplinaire HAL, est destinée au dépôt et à la diffusion de documents scientifiques de niveau recherche, publiés ou non, émanant des établissements d'enseignement et de recherche français ou étrangers, des laboratoires publics ou privés. 


\section{Accepted Manuscript}

Title: The impact of english dominance on literature and welfare

Author: Jacques Mélitz

PII:

S0167-2681(07)00124-2

DOI: $\quad$ doi:10.1016/j.jebo.2006.10.003

Reference: $\quad$ JEBO 2105

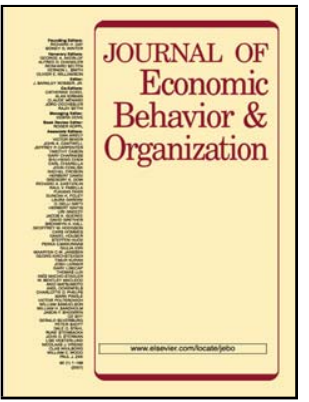

To appear in: Journal of Economic Behavior \& Organization

Received date: $\quad$ 29-6-2005

Revised date: 29-6-2006

Accepted date: $\quad$ 13-10-2006

Please cite this article as: Mélitz, J., The impact of english dominance on literature and welfare, Journal of Economic Behavior and Organization (2007), doi:10.1016/j.jebo.2006.10.003

This is a PDF file of an unedited manuscript that has been accepted for publication. As a service to our customers we are providing this early version of the manuscript. The manuscript will undergo copyediting, typesetting, and review of the resulting proof before it is published in its final form. Please note that during the production process errors may be discovered which could affect the content, and all legal disclaimers that apply to the journal pertain. 


\title{
THE IMPACT OF ENGLISH DOMINANCE
}

\author{
ON LITERATURE AND WELFARE
}

\author{
Jacques Mélitz*
}

June 5, 2007

Market forces privilege the translation of English fiction and poetry into other languages, and thus pose a danger for the accumulation of capital in the form of literature. A variety of source languages in translations makes literary capital more valuable as such. Further, the importance of writing in English in order to reach a world audience lowers the pool of talent capable of contributing to literature. The paper starts with a model of the world publishing market that explains why the dominant language acquires a disproportionate share of translations. Then the reasoning proceeds from theory to the empirical evidence.

*Heriot-Watt University, Edinburgh, CREST-INSEE, Paris, and CEPR. Economics Department, Mary Burton Building 1.7, Edinburgh EH14 4AS. UK. E-mail: j.melitz@hw.ac.uk. Tel.: 44-131-4513626. This paper is a thorough revision and extension of "English-Language Dominance, Literature and Welfare," CEPR Paper no. 2055, 1999. I owe a particular debt to Alain Desrosières and Susan Layton for many useful exchanges and to Hervé Renard of the Centre National du Livre for data and data sources. I also benefited from comments by William Baumol, Christophe Chamley, Michele Fratianni, François Grin, Johan Heilbron, Hélène Rey and Marc Raeff, two referees and the editor on previous drafts. 


\section{Introduction}

If language served merely to convey information, then a single language would be optimal in the long run. In any hypothetical passage to this optimum, a lot of linguistic capital would be lost and its possessors would suffer greatly, but once the people who lost this capital were gone, the new generations would have no reason for regrets, except out of concern over the welfare of the dead (which would pass with time) or out of historical interest (which a specialized minority could serve). The logic of these remarks possibly explains the usual complacency in many places about the spread of English as a lingua franca ${ }^{1}$ in the world. But language is not simply a means of communication. It is also a source of pleasures, interests, and passions, and the resulting "utilities" might grow with variety of tongues, if not otherwise through the medium of translations. In this respect, a single language could very well impoverish the future, and the spread of English might not be a blessing. I will develop this viewpoint here exclusively in one connection: as regards the accumulation of capital consisting of literature. Quite precisely, my argument will be that the tendency of an integrated world market to privilege the translation of English fiction and poetry into other languages for reading or listening enjoyment may damage the production of world literature and in this respect make us all worse off. Of course, this will not permit me to generalize about the net gains or losses of a common language, which would require consideration of many other factors, including the benefits of ease of communication (see Dalmazzone 1999 and Grin 1996).

The bulk of fiction and poetry that provides us stimulation or entertainment loses interest very quickly. This is true both for the written variety and the spoken one offered on radio, video, and television, or in the cinema. However, a tiny fraction of the current production is destined to survive and to continue to give pleasure to future generations. This fraction represents capital. I will term this particular capital, in written form, "literature," and this capital will be the one whose growth, I maintain, will possibly be threatened by the dominance of English. In a section dealing with the evidence, I will also consider the extent to which the

1 The terms vary: in pertinent works, Hagège (1994) refers to a "vehicular" language; de Swaan $(1993,1995)$ to a "central" language. 
reasoning applies to fiction and poetry in audiovisual form, including the motion picture (the "seventh art").

The argument will proceed in four parts. In the first one, I will outline the general argument that concentration of translations out of a single language reduces welfare. This section will set forth the basic reasoning: most of the empirical support will come later. In the second part, I will propose a theoretical model showing that the ordinary working of the world publishing market poses a danger of an excessive degree of concentration of translations if one language dominates the rest. According to the model, if one language is sufficiently larger than others in the sales of original-language works, it will tend to crowd out the rest in translations. Authors writing in the dominant language will not have a better chance of publishing an original manuscript. Quite the contrary, those doing imaginative writing in other languages will face much softer conditions for publication than those writing in the major one. However, with respect to translation and therefore the prospect of reaching a world audience, those writing in the dominant language are privileged. In addition, based on the model, reductions in the technical barriers to diffusion of imaginative works will increase the advantage of the dominant language in translations. At the limit, improvements in the technology of diffusion can even lead virtually to the exclusive translation of imaginative works from the dominant language into the rest.

The third part of the argument will substantiate the conclusions of the market analysis regarding translations. The section will begin with the existing distribution of languages in the world publishing market. It will then proceed to show that translations of fiction indeed tend to be disproportionately in favor of the leading language, English, whereas translations of fiction into English are incommensurately small. Furthermore, with the advance of mass communications since the sixties, the importance of English in translations has risen, and this has happened despite the fact that the share of English in the market as a whole has fallen off as a result of demography and increases in literacy rates. Discussion of audiovisual entertainment will enter at this stage.

The fourth part of the argument will enlarge the empirical support for the basic propositions in the early welfare discussion. Throughout the paper, I will take the spread of English 
as a world language for granted. Why English has assumed the extraordinary position it holds today as a world language is a separate and important topic, on which others have written and I will have nothing to say. ${ }^{2}$

\section{The Welfare Argument}

Most creative writing loses interest shortly after publication. A tiny fraction of the writing survives. With the passage of time, the costs of keeping the services of the surviving works available cease to be at all commensurate with the benefits. Selection by publishers no longer absorbs resources. Copies can pass from hand to hand without discouraging the authors or hurting their current competition (which partly writes for a different audience and in any event will often benefit from complementarities). The consumer surplus also increases with the expiration of royalty rights. Thus, the survival of any current writing, or "literature" in my proposed usage, is a social windfall. In some individual cases, such as the major classics, the bonus to society is colossal. ${ }^{3}$

For various reasons, however, the contribution of living authors to the trickle of current output that survives as literature depends heavily on translations. First, as an empirical fact, only a fraction of the reading public reads any particular language, especially for pleasure. This is as true for English as for any other tongue. Thus, accessibility to a work only in the original tongue diminishes the probability of survival. Further, surviving works of fiction often possess wide world appeal and therefore tend to be translated in many languages. On this next ground, not only does wide translation enlarge the audience, but it is an indicator of broad appeal. Finally and very significantly, people with creative talents cannot easily switch languages. This is so because of their reliance on literary expression rather than mere communication. As a result, they depend heavily on translations.

It follows that the concentration of translations into a single language will do harm. The

\footnotetext{
2 See, in particular, Crystal (1997), and for a more enthused account of English's rise to its present perch of dominance, McCrum, Cran, and MacNeil (1992).

${ }^{3}$ For a different (though altogether compatible) view of the social productivity of creative writing, see Breton (1999).
} 
reduction in the audiences for most works will reduce their probability of survival. The inability of creative writers to switch languages will intensify this result. Those who write in languages other than the dominant one will lose incentive to invest in their own talents. Local success will come too easily while world audiences are out of reach. Because of the lower personal investment and visibility for all who do not write in the dominant language, concentration of translations in one language will then tend to narrow the pool of existing talents capable of producing literature. I will develop this argument more fully in Section IV.

Most obviously of all perhaps, the concentration in a single language would do damage simply because variety of source languages in translations increases the value of literary capital as such. In the case of literature, as opposed to other uses of language, language does not serve merely to communicate subject-matter - say, a story line - but is itself an essential source of stimulation and enjoyment. Therefore, it is futile to argue that everything would be the same if all potential contributors to literature wrote in the same language. We might as well pretend that there would be no loss if all musical composers wrote for the cello. A translation can only approximate the rhythms, sounds, images, allusions and evocations of the original, and in the case of literature, these aspects are essential. Thus do the classics of world literature continue to be translated anew into the same languages as before. The confinement of contributions to literature to original writings in English would therefore bring inevitable losses.

Accordingly, translations have played a major role in the development of modern languages, and there is every reason to think that they are needed for the continued development of these languages. Quite significantly, the issue is as much one of translations into a language from a variety of other tongues as one of translation out of a language into a variety of others. English has been expanded in the past by the translation of classics dating from Homer onwards. ${ }^{4}$ Continuing translations into English are required to stretch the language further and open up new literary veins. The strict or nearly strict translations of original works in English into other tongues would therefore damage English readers along with rest. Indeed, from the

\footnotetext{
${ }^{4}$ On the fascinating history of translations of Homer into English, see Steiner (1993).
} 
perspective of enrichment from other languages, English readers might suffer more since the rest would still benefit at least from the inspiration that the English language and the cultural experiences and perceptions of English authors would provide.

I now turn to a simple model of the publishing market where a dominant language threatens nearly to drive out all the rest in translation.

\section{Theory}

(a) The publishing market: a start

In order to model the publishing market, I will begin with the case of a single world language and the absence of any technical barrier to the worldwide diffusion of any written work. The article will then proceed successively to introduce a problem of distribution and a variety of languages.

Let the number of titles or separate works produced in the publishing industry be $n$, the number of copies of all works in the aggregate be $\mathrm{Q}$, and the total world population of readers be N. Q/n then stands for the average number of copies per work, and if we identify output and sales, $\mathrm{Q} / \mathrm{N}$ is the average number of works purchased by the individual consumer. For the moment, I will assume that copies of all separate works sell at the same price P regardless of differences in the popularity of individual works. As we will see later, so long as differences in page length, quality of print, illustrations, binding, and so forth are irrelevant, the assumption will follow from the analysis. The demand for works by the individual consumer supposedly depends, in an ordinary way, on own-price P, the prices of alternative forms of leisure, individual incomes and tastes. Works of an earlier vintage, or literature, represents one of the alternative forms of leisure. Let us suppose next that the prices of all alternative leisure activities, without exception, and all individual incomes, are given. Consequently, if utility functions of individual consumers are completely separable in imaginative works, the aggregate world demand for these works can be written simply as

$$
\mathrm{Q}=\mathrm{f}(\mathrm{P}) \mathrm{N} \quad \mathrm{f}^{\prime}(\mathrm{P})<0
$$

This elementary formulation will serve us throughout the discussion. I will always suppose that at a given price $\mathrm{P}$, people want some set aggregate volume of currently produced imagina- 
tive writing for stimulation and entertainment. In other words, they will wish to put aside a fixed amount of their time for this particular leisure activity as opposed to all others: sports, play, audiovisual entertainment, and the rest.

As indicated already, the critical question is the number of separate imaginative works that will satisfy the aggregate demand Q. Obviously, each of the works read by the individual must differ and in this sense preference for variety is important. But the typical form of DixitStiglitz (1977) utility function cannot serve since this formulation would mean that everybody reads everything, which is emphatically wrong. Quite the contrary, everyone reads a miniscule portion of the total output of works, and if $\mathrm{n}$ is very large it is only because of differences in consumer tastes and authorial abilities to satisfy those tastes. Some people like mysteries, others prefer romances, and still others favor science fiction. Moreover, individual readers prefer different authors, and writers supplying a particular class of works will therefore seduce a different public. I will assume that based on the heterogeneities of tastes and talents, the audiences of existing talents can be arranged in descending order according to a general function as follows:

$$
\hat{\mathrm{q}}=\mathrm{g}(\mathrm{n}) \quad \mathrm{g}^{\prime}(\mathrm{n})<0
$$

$\hat{\mathrm{q}}$ is then the maximum audience of the least popular work at any given $\mathrm{n}$.

Figure 1, which treats $\mathrm{n}$ as a continuous variable, depicts the situation. The line designated $g(n)$ represents equation (2). Accordingly, the most popular work could sell a maximum of $\overline{\mathrm{q}}_{\max }$ copies, and the total number of works could not exceed $\mathrm{n}_{\max }$, at which point no one would pay a cent for the next best imaginative work. The function $\bar{g}(\mathrm{n})$ shows the corresponding (maximal) averages of audiences $(\overline{\mathrm{q}})$ at different $\mathrm{n}$ values. $(\overline{\mathrm{g}}(\mathrm{n})$ and $\mathrm{g}(\mathrm{n})$ stand in the usual relation of an average to a marginal value.) Simply to illustrate, suppose that each consumer reads at least one work (therefore $\mathrm{Q} \geq \mathrm{N}$ ), and also suppose that $\mathrm{N}=\mathrm{OABC}$. Then the relevant downward sloping section of the $\mathrm{g}(\mathrm{n})$ function starts at point $\mathrm{D}$ along the vertical axis and the relevant one of the $\bar{g}(\mathrm{n})$ function at point $\mathrm{B}$. 
FIGURE 1

\section{THE HETEROGENEITY OF TASTES AND TALENTS}

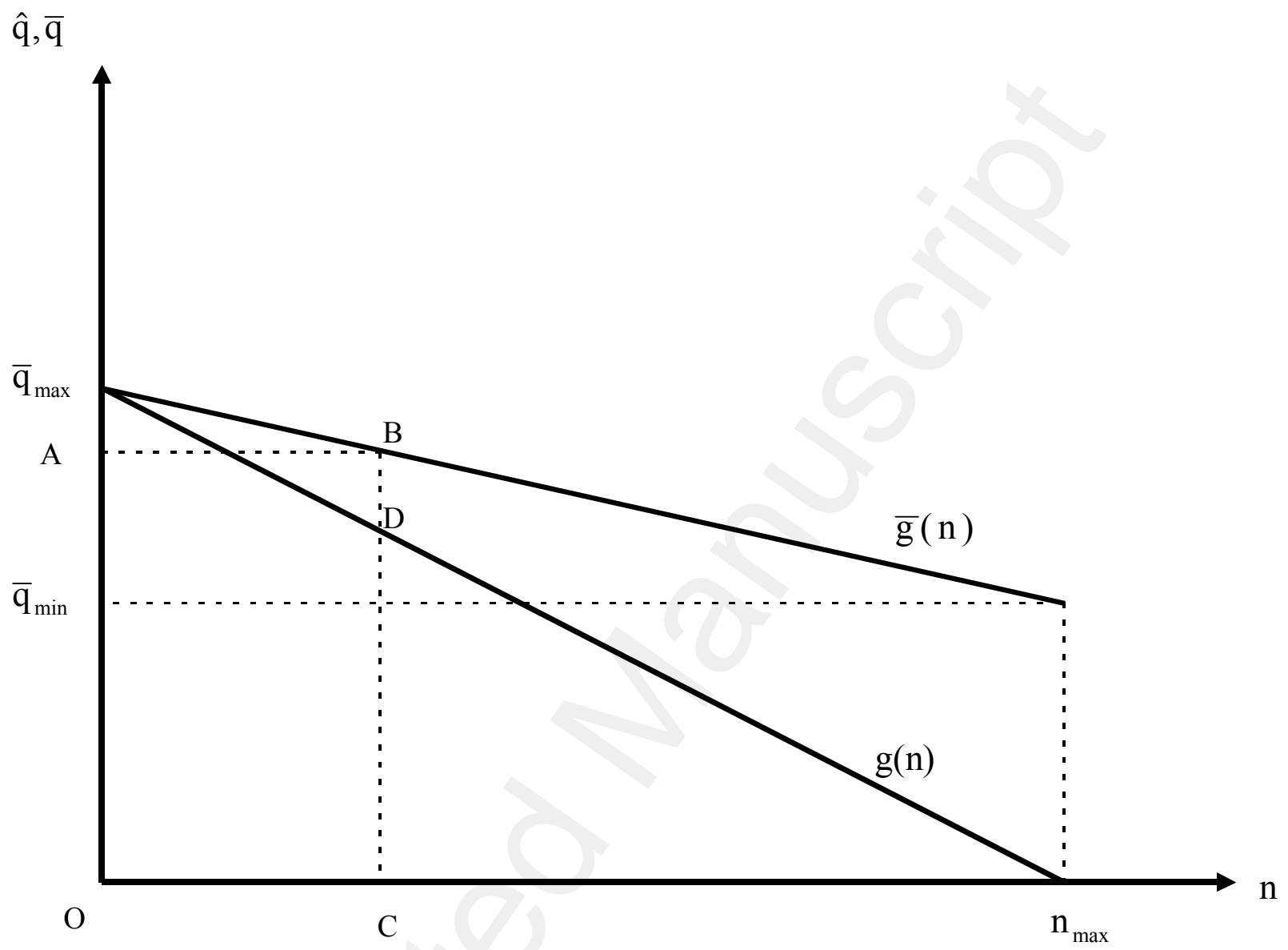

Supply requires far more development. Authors do not sell directly to readers; publishing firms do so instead. These firms perform an essential service of selection since they decide which works to accept for publication. The firms bear four types of costs: a cost per individual work $\mathrm{F}$, a cost per individual copy of a work $\mathrm{V}$, a royalty rate $\mathrm{R}$ for sales above a minimum profitable level, and overhead cost $\mathrm{O}$. F is fixed per title, $\mathrm{V}$ is variable per title, both $\mathrm{F}$ and $\mathrm{V}$ are variable per publisher, and only $\mathrm{O}$ is fixed per publisher. The cost $\mathrm{F}$ comprises two ele- 
ments: first, a flat payment to the author for his time; and second, in-house expenses of selecting and editing a manuscript. The cost $\mathrm{V}$ consists of the material support, such as the paper and binding. The overhead cost, $\mathrm{O}$, relates to the processing of rejected manuscripts, which is an essential expense. I will also assume, very significantly, and in line with these definitions, that the author of the least-selling manuscript receives the flat fee incorporated in $\mathrm{F}$ but no royalties.

Let us suppose next that publishers select manuscripts correctly in order of popularity. Consequently, the profit-maximizing condition of equality of marginal revenue and marginal cost at the individual level is

$$
\mathrm{P} \hat{\mathrm{q}}=\mathrm{F}+\mathrm{V} \hat{\mathrm{q}} \text {, or } \mathrm{P}=(\mathrm{F} / \hat{\mathrm{q}})+\mathrm{V}
$$

where $\hat{\mathrm{q}}$ is now not only the maximum audience of the least-popular work for any given number $\mathrm{n}$, as before, but also the sales of the least-popular work that firms accept for publication. On the further assumption of perfect competition in the publishing industry, $\mathrm{P}$ additionally represents marginal revenue.

Perfect competition means zero profit, and therefore in equilibrium for the industry,

$$
P Q=n F+Q V+\Theta+R[Q-n \hat{q}] \quad P(Q-n \hat{q}) \geq \Theta
$$

where $R$ is the royalty rate that authors obtain for sales above $\hat{\mathrm{q}}$ and $\Theta$ is the overhead cost for the industry as a whole or the overhead cost borne by the individual firm $\mathrm{O}$ times the number of firms. $\Theta$ will be taken to be exogenous. ${ }^{5}$ The condition $P(Q-n \hat{q}) \geq \Theta$ must obviously be satisfied since otherwise firms would not be able to meet their overhead costs. It is important to note that on this ground alone, a certain unevenness in sales is essential: if firms sold exactly $\hat{\mathrm{q}}$ copies of all individual works, the overhead costs would not be met and the market could not exist. Equation (4) evidently determines R, the royalty rate. If we eliminate $\hat{\mathrm{q}}$ from this equation based on equation (3), as we can, the solution for $\mathrm{R}$ becomes

$$
\mathrm{R}=(\mathrm{P}-\mathrm{V}) \frac{(\mathrm{P}-\mathrm{V}) \mathrm{Q}-\mathrm{nF}-\Theta}{(\mathrm{P}-\mathrm{V}) \mathrm{Q}-\mathrm{nF}}
$$

5 This merely says that the total number of manuscripts that needs to be disposed of by the publishers is independent of the number of publishers. The supposition has no role except to keep the competitive solution independent of the number of firms. 
It follows that in the absence of $\Theta, \mathrm{R}$ would simply equal $\mathrm{P}-\mathrm{V}$ and total royalties would be $(\mathrm{P}-\mathrm{V})(\mathrm{Q}-\mathrm{n} \hat{\mathrm{q}})$, but because of $\Theta, \mathrm{R}$ is smaller and $\mathrm{R}$ and $\Theta$ are inversely related.

Quite critically, according to the formulation, publishing firms earn no more income on best-sellers than any other works. In light of the determination of R, their average cost, inclusive of royalties, always equals their marginal cost. This situation supports the conclusion of a uniform price. The idea is simple: writing talent is scarce, but there are no barriers to entry into publishing. Therefore, those who can write very popular fiction and poetry will capture all the rents. Their surpluses will not be bid away through competition. ${ }^{6}$

In order to close the system, the integration of equation (2) is necessary:

$$
\sum_{\mathrm{n}=1}^{\mathrm{n}^{*}} \mathrm{~g}(\mathrm{n}) \Delta \mathrm{n}=\mathrm{Q}
$$

( $\mathrm{n}$ is discrete, contrary to figure 1 ).

Equations (2), (3) and (6) form a supply block. Together, they give rise to a positively sloping supply of output, shown in figure 2. At any particular price, equation (3) sets an exact level of $\hat{\mathrm{q}}$. As price rises, this profit-maximizing level falls, and as a result, based on equation (2), $\mathrm{n}$ must rise. From equation (6), there follows a corresponding rise in Q. Since $\hat{\mathrm{q}}$ can never become negative, the supply heads toward some upper limit as P climbs, and the slope of supply therefore becomes progressively steeper, as depicted in the graph. ${ }^{7}$ For example, in the

${ }^{6}$ One delicate point in the analysis is the simplifying assumption that all authors receive the same royalty rate per copy sold above $\hat{\mathrm{q}}$. It could easily be imagined, quite differently, that authors of best-sellers would command a higher royalty rate than the rest since the fixed cost $\mathrm{F}$ of producing their work constitutes a smaller proportion of total revenues than that of producing others'. However, firms could only promise higher royalty rates to these authors if they could determine beforehand that the sales of their works would be higher. Yet doing so would require special investigation and effort, which I will suppose to be too high to be warranted. Consequently, publishers simply undertake the same set effort in selecting and editing all accepted manuscripts, just enough to assure that sales will equal or exceed $\hat{\mathrm{q}}$. It could still be objected, in this case, that the talented authors might induce firms to group works into classes based on probable sales and to pay a higher royalty rate on those that can be expected to sell much better than the rest (in the same way that bankers divide borrowers into risk classes to whom they charge different interest rates). I assume that even this lower degree of effort would be too costly.

${ }^{7}$ Mathematically,

$$
\frac{\Delta \mathrm{Q}}{\Delta \mathrm{P}}=\frac{\Delta \hat{\mathrm{q}}}{\Delta \mathrm{P}} \frac{\Delta \mathrm{Q}}{\Delta \hat{\mathrm{q}}}=-\frac{\mathrm{F}}{(\mathrm{P}-\mathrm{V})^{2}} \mathrm{~g}^{\prime}(\mathrm{n}) \Delta \mathrm{n}
$$


case of the $g(n)$ function in figure 1, the upper limit to output would be given by the area of the triangle formed by the origin, $\overline{\mathrm{q}}_{\max }$ and $\mathrm{n}_{\max }$ (which would equal OA in figure 2 ). The condition $\mathrm{P}(\mathrm{Q}-\mathrm{n} \hat{\mathrm{q}}) \geq \Theta$ sets the minimal point on the supply curve.

FIGURE 2

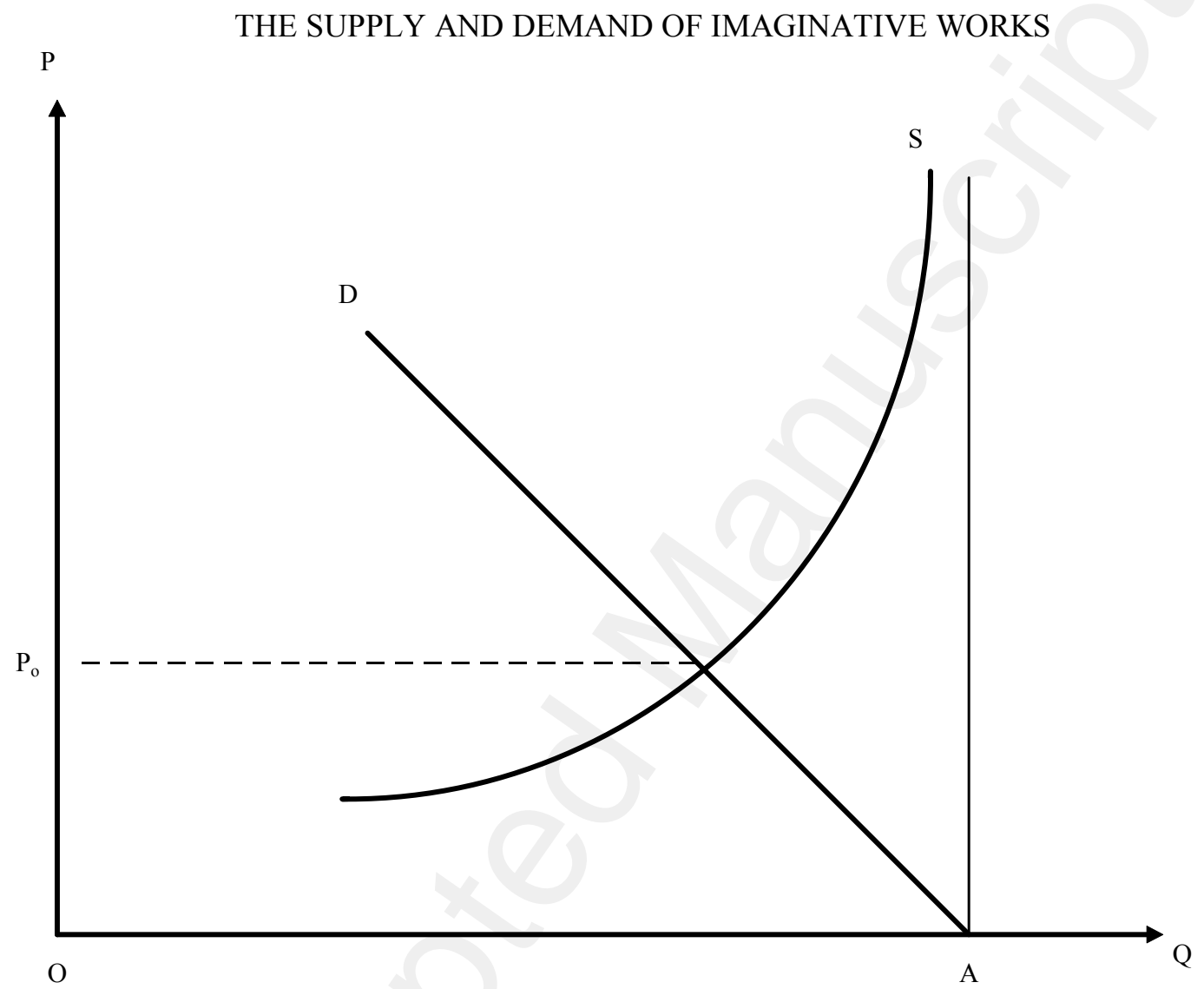

Note that the individual firm faces an ordinary U-shape average cost curve, exclusive of royalties. As the number of manuscripts published by the individual firm $\mathrm{j}, \mathrm{n}_{\mathrm{j}}$, goes up, the average cost falls at first because of the overhead costs $\mathrm{O}$ facing the firm, but the marginal cost steadily rises as the fixed cost $\mathrm{F}$ per title increases in relation to $\hat{\mathrm{q}}$. (The contribution of $\mathrm{V}$

Since $\mathrm{g}^{\prime}(\mathrm{n})<0, \Delta \mathrm{Q} / \Delta \mathrm{P}>0$. Further,

$$
\frac{\Delta^{2} \mathrm{Q}}{\Delta \mathrm{P}^{2}}=\frac{2 \mathrm{~F}}{(\mathrm{P}-\mathrm{V})^{3}} \mathrm{~g}^{\prime}(\mathrm{n}) \Delta \mathrm{n}
$$

(if $\left.\mathrm{g}^{\prime \prime}(\mathrm{n})=0\right)$ and therefore $\frac{\Delta^{2} \mathrm{Q}}{\Delta \mathrm{P}^{2}}<0$. 
is irrelevant for the U-shape since it is a constant.) As long as demand in the industry is above the minimum necessary to permit production (as in Figure 2), where marginal and average cost are equal, the firm will produce along the upward sloping portion of the average cost curve. The difference between price and average cost will go entirely to royalties: it will not encourage entry.

The model is now complete: equations (1), (2), (3), and (6) represent demand and supply, and determine $\mathrm{Q}, \mathrm{P}, \hat{\mathrm{q}}$, and $\mathrm{n}$ simultaneously, while $\mathrm{R}$ follows as a residual from equation (4). It will now be possible to proceed more quickly as we remove the assumption of absence of any problems of worldwide distribution, and following, lift that of a single world language as well.

\section{(b) A distribution problem}

Suppose next that the supplier cannot make available works of fiction to everybody in the world at the same cost. Rather, each firm operates in a particular circuit, and furnishing copies to customers located off this circuit entails special costs of transportation and intermediation. ${ }^{8}$ The distribution costs consequently afford authors protection for sales up to a certain point, but only up to a point since authors must yield exclusive publishing rights to a single firm and cannot publish the same work with several publishers (as otherwise publishing might cease to be profitable and the whole market might fold). As a result, more manuscripts will be accepted for publication. Some previously rejected (or unwritten) manuscripts now find a market niche (less severe competition). Correspondingly, the most popular works do not sell as well as before. Since marginal costs are higher, price P evidently goes up, but total royalties go down as demand is the same in the industry while costs are higher.

\section{(c) Variety of Languages}

Interestingly enough, different languages yield similar results. Like distribution costs, they impose a barrier to readership. In case of a variety of languages, some works that would

\footnotetext{
8 This opens the way for some of the familiar models of the spacing of consumers and firms, such as Hotelling's (1929) placing them on a straight line or Salop's (1979) putting them along a circle, but contrary to usual applications of these models, the firms are numerous and perfectly competitive. I will not pursue this avenue of investigation here.
} 
otherwise not appear find their way into print, and the most successful authors reach smaller audiences and earn lower rents. However, translations limit the barriers imposed by languages. These activities restrict the fall in $\hat{\mathrm{q}}$ and the rise in $\mathrm{n}$. Still, translations cannot avoid either altogether since they are costly. Furthermore, different languages correspond to differences in cultures and tastes that translations cannot totally surmount.

Once separate languages enter, we must distinguish the cost of publishing a work in the original language and in translation. Let the cost of translating a work, as such, be $\mathrm{C}_{\mathrm{tr}}$ and that of selecting and editing a manuscript for translation be $\mathrm{C}^{*}$. Given multiple languages, publishers will equate the marginal cost of producing a translated and an original-language manuscript. Since variable costs V and distribution costs will be the same in either case, firms will therefore set $\mathrm{C}_{\mathrm{tr}}+\mathrm{C}^{*}$ equal to $\mathrm{F}$ at the margin. This means that $\mathrm{C}^{*}$ must be inferior to $\mathrm{F}$. One factor that makes it possible to meet this condition is that sales in the original language provide an important gauge of the probable success of a translation, although it is not the only gauge (as otherwise there would be no costs of selection $C^{*}$ ). The empirical evidence on this point is clear: translations are indeed concentrated on works already in print, and especially on a minority of these works that has sold particularly well in the original language, even though this minority still constitutes a selection. As one student of the publishing industry observes: "Not surprisingly, what people most want to read [in translation] are other people's bestselling literature" (Curwen 1986, p.19). ${ }^{9}$ Except in connection with the selection of manuscripts for publication, however, publishing firms behave the same way as regards originallanguage manuscripts and translations. They spend $\mathrm{F}$ on each and every single work, or a sum $\mathrm{C}_{\mathrm{tr}}+\mathrm{C}^{*}$ equal to $\mathrm{F}$ in the case of each translated one, and simply assure themselves of sales equal or greater than $\hat{\mathrm{q}} \cdot{ }^{10}$

\footnotetext{
${ }^{9}$ For other sources, see Ganne and Minon (1992) and Colas (1992). I propose dropping the earlier simplifying assumption that the selection is perfect at this stage.

${ }^{10}$ Once again, the only point of this assumption is to avoid any tendency for firms to pay different royalty rates to different authors. As an additional consideration, in the case of translations, the author has already been compensated for the opportunity cost of his time and need only be paid royalties. On the other hand, the rights to translate must be purchased from the original publisher. Industry sources agree that those two factors tend to cancel out. Thus, the basic difference between publishing a translation or an original manuscript surrounds the issue of translation rather any matters of rights and royalties. See Imrie (1992, p. 132).
} 
On this view, the first-order condition of profit maximization does not change: the minimum-sales of the translated works, $\hat{\mathrm{q}}$, will be the same as the minimum-sales of the original-language works, $\hat{\mathrm{q}}$ ( since $\mathrm{F}=\mathrm{C}_{\mathrm{tr}}+\mathrm{C}^{*}$ ). $\hat{\mathrm{q}}$ will also vary negatively with the number of languages $\mathrm{L}$ and positively with the number of translations $\mathrm{m}$, where $\mathrm{m}$ refers to all separate translations no matter how many times the same works are translated into different languages. Given L, a separate equation for $\mathrm{m}$ is thus necessary. To handle the problem, we shall assume that the ratio of translations to original-language titles, $\mathrm{m} / \mathrm{n}$, is a strict negative function of the ratio of costs of translation to total receipts and positive function of the popularity of the average selection, as indicated by the ratio of royalties to total receipts. Evidently best-sellers have particularly high ratios of royalties to sales. An appendix sets forth the whole model in the dual presence of distribution costs and multiple languages. ${ }^{11}$

To repeat, a variety of languages multiplies the number of publications by affording every writer more protection. The curse of Babel (Genesis: 11.5-7) exerts much the same influence on market events as distribution costs, but translations limit the multiplication by overcoming linguistic hurdles to some extent.

\section{(d) Dominant Market Size and Advances in the Technology of Distribution}

According to the previous analysis, only popular works in the original will be translated, but the analysis does not tell us how translations will be divided between languages. There are two sorts of reasons to think that translations will be concentrated in large languages. One has to do with costs, the other with the quality of authors. As mentioned earlier, firms face a cost of selecting, translating and editing a translated manuscript $\mathrm{C}_{\mathrm{tr}}+\mathrm{C}^{*}$, but it is reasonable to consider that this cost is higher if a firm translates ten works from ten original languages than from a single one. Thus, if a firm already translating from English into the home language begins to translate from Panjabi, it will incur higher costs $\mathrm{C}_{\mathrm{tr}}+\mathrm{C}^{*}$ at the margin. In other words, there are economies of scale from translating fewer languages, which will then favor concentration on large languages. In addition, suppose that up to a point, larger initial investment in translating out of a particular language reduces the subsequent marginal

11 This appendix is available on the JEBO website. 
cost of screening, editing and translating manuscripts. Depending on the exact parameters, this could well encourage still greater concentration on large languages.

The second factor working in favor of large languages concerns the authors. Popular authors in these languages have succeeded against longer odds. They send a stronger signal of appeal to a world audience. Consider two language communities, one 100 times larger than the other. Given any similarity of tastes within each community, the number of different authors that the people in the larger one read will be much less than 100 times larger. The competition therefore will be much stiffer in the larger community, and popular acclaim there will imply much more ability to satisfy readers than similar triumph in the smaller community.

In order to see just how skewed the distribution of translation can be on the basis of these factors, assume that one-quarter of the world uses one language while the other threequarters divides up into numerous, small language communities. As a result, the only massive sales of original-language works are in the dominant language. In that case, virtually all the translations may come from works appearing originally in this language. True, some highly popular original-language works in the smaller languages probably will still be translated due to sampling of the best-sellers in these languages. ${ }^{12}$ Notwithstanding, the dominant language will conquer most of the field.

Interestingly enough, publications in the other languages could still thrive. In fact, those who write in the other languages could even possess a substantial advantage at home because of the costs of translation and local preferences for their modes of expression and sources of inspiration. Correspondingly, the most difficult language in which to publish would still be the dominant one because of the larger pool of talents that is competing for attention there as well as the smaller percentage of them that can succeed. Still, the only writers with any notable chance of translation would be those who use the dominant tongue.

If we assume the wholesale elimination of the distribution problem while we retain the

\footnotetext{
12 Would risk aversion raise the sampling of small languages? The answer to this intriguing question is ambiguous. On the one hand, it could do so because such sampling would increase the variety of the material for review, but on the other, it might not because the sampling would raise costs (by failing to exploit the previous economies of scale).
} 
hypothesis of a dominant language, then translations from this language into other ones could also grow by leaps and bounds. Suppose that mass communications and advances in computer technology remove distribution costs entirely. Every publisher can now reach any reader on the globe at the identical cost. In the small-language communities, however, the language barrier could still keep the size of the readership of any specific work in the home tongue from rising significantly. By contrast, in the dominant language community, the readership could now concentrate on a far narrower selection of works. As a result, translations of works issuing from the dominant language could flourish. ${ }^{13}$

Once again, if we look at the matter in relative terms, the authors exercising the dominant language could be those who suffer mostly. Each of them now needs to compete with every outstanding talent on earth who happens to write in his tongue. Each one's effective loss of protection may therefore be great, and his individual chances of publication may drop precipitously. For the other writers, whose effective protection had always come essentially from language, the only important rise in competition could come through translations, and there could be far less change. Nevertheless, nearly all the big prizes will go to authors exercising the major language; nearly all the "superstars" will hail from their midst. ${ }^{14}$

It is interesting to consider also the more relevant empirical case where one language

${ }^{13}$ In terms of figure 1 (regarding the world market), the problems of translation and distribution not only diminish $\overline{\mathrm{q}}_{\max }$ and raise $\mathrm{n}_{\text {max }}$, but also alter the general profile of sales in different ways. Translation costs favor the high-sales end of the spectrum and therefore make the sales curve highly convex. Distribution costs, on the contrary, diminish the upper tail of sales and reduce the previous convexity. Therefore, a reduction in the costs of distribution causes the convexity of the sales curve to rise, in accordance with the text. Note also that the figure must now be interpreted as pertaining strictly to sales and is no longer also an exact mirror of the heterogeneities of tastes and talents.

14 The allusion to Rosen (1981) is obviously intended, but whereas Rosen was concerned with explaining why enormous rents could be earned by possessing just a little more talent than the next person, I am not especially interested in the private dividends of having an edge. A word might also be said about a seeming contradiction with Baumol and Bowen (1966). In a highly influential work, these two writers emphasize the tendency of technological progress to reduce profits in the arts. Of course, my stress is on the opposite tendency for such progress to increase the profits of writers (both in the aggregate and for a minority of them in particular). But Baumol and Bowen focus on the performing arts. If the artist need not be physically present - more exactly, if the same artistic output can continue to serve an ever-growing public without any renewed effort on the artist's part - Baumol and Baumol (1984) agree that improvements in mass communications can only increase the rents. 
community is notably larger than the rest, but a number of the others are big enough to possess a sizable number of translated works of their own. Evidently, in this case, the dominant language would still corner a disproportionate share of translations and garner the lion's share of the producers' gains from improvements in communications and distribution. Less obvious, however, is how few the translations into the dominant language could continue to be.

Let the leading language community represent $\mathrm{N}_{\mathrm{i}} / \mathrm{N}$ of all readers, $\mathrm{m}_{\mathrm{i}} / \mathrm{m}$ be the ratio of the translations of works from this language into others, and this ratio be less than one. The proportion of translations from other languages into the leading language could then be less than $\mathrm{N}_{\mathrm{i}} / \mathrm{N}$ because of the more intense competition for publishing in this language. However, suppose to make things simple, that we disregard this factor (which can only work toward lower translations into the dominant language) and take the proportion of the translations of the other languages into the leading one as equal to $\mathrm{N}_{\mathrm{i}} / \mathrm{N}$. If we signify the translations into the dominant language as ${ }_{\mathrm{i}} \mathrm{m}$, we then have

$$
\frac{{ }_{\mathrm{i}} \mathrm{m}}{\mathrm{m}}=\left(1-\frac{\mathrm{m}_{\mathrm{i}}}{\mathrm{m}}\right) \frac{\mathrm{N}_{\mathrm{i}}}{\mathrm{N}}
$$

The share of translations from the other major languages into the dominant one will fall short of the latter's population share and will do so in direct proportion to $\mathrm{m}_{\mathrm{i}} / \mathrm{m}$. Since the ratio $\mathrm{m}_{\mathrm{i}} / \mathrm{m}$ will exceed $\mathrm{N}_{\mathrm{i}} / \mathrm{N}$ on previous grounds, the gap between $\mathrm{m} / \mathrm{m}$ and $\mathrm{m}_{\mathrm{i}} / \mathrm{m}$, or translations into and out of the dominant language, could be great and the ratio $\mathrm{i} / \mathrm{m}$ quite small.

III. The Empirical Evidence about Publishing and its Possible Extension to the Audiovisual $\underline{\text { Sphere }}$

An examination of the empirical evidence on the dominance of English confirms the relevance of the previous theory.

(a) Publishing

The pertinent data about the relative sizes of world languages in publishing concern titles under the heading of fiction. The yearly reports of UNESCO provide relevant annual series for published titles in the post-World War II period, subdivided by country and language. The UNESCO classification of central interest is "general literature," which encom- 
passes "fiction," "literature," and "poetry." Although this classification comprises reeditions of all sorts, including the classics, and therefore exceeds the number of currently produced titles (n) in the previous discussion, the statistic is nevertheless close to our present concerns. Table 1 shows the respective shares of the seven major languages in the world in the publishing of fiction at ten-year intervals, in 1971, 1981, and 1991, where 1991 is the latest year for which the table can be drawn. In order of importance in 1991, the languages are English, Chinese (Mandarin), German, Spanish, French, Russian and Japanese. (Next in order, alphabetically, are Italian, Korean and Portuguese.) The most reliable figures are those at the top of the table, which regard the shares of the languages in total titles. However, the relevant shares are those of titles in the literature classification. The rest of the table tries to correct for this problem.

The three middle rows of the table (for 1971, 1981, and 1991) provide an approximation for the ratios of titles in the literature classification to total titles in the seven languages (only six in 1971 when Chinese was missing). The approximation rests on incomplete yet considerable figures for total titles in the literature classification. Based on the approximation, the ratio of titles of literature for each of the languages to total titles of literature in the world can then be derived by assuming that the sum of the seven languages' contributions to total titles and to titles of literature are both the same in percentage terms (63 percent in 1971, 64 in 1981, and 60 in 1991). This is what is done at the bottom of the table. As far as the assumption is inexact, the percentages at the bottom of the table are off, but their relative order is not affected, and this relative order is our main concern.

Three main features of the results in Table 1 emerge. First, English is far and away the most important language in the world, almost twice as important as the next one in the ranking. Second, Chinese and Russian swap places in 1981 and 1991, Chinese jumping up from last to second place with Russian doing about the opposite. The ascendance of Chinese (Mandarin) surely reflects the increase in standard of living and literacy rates in this populous nation. On the other hand, the decline of Russian is linked to the break-up of the Soviet empire 
in $1990 .{ }^{15}$ In addition, Russian's eminent position behind English in 1971 at the top of the table is exaggerated by a large number of political tracts in total titles, as is seen in the lower ranking of Russian for this year in the bottom of the table where the tracts are not included. The same exaggeration persists to a lesser degree in 1981. Third, the table exhibits the wide distinction between the demographic and the publishing data about languages. There may be more speakers of Chinese (Mandarin) than English in the world (English only comes close because of its importance as a second language), ${ }^{16}$ but English is still about twice as large as Chinese in publishing in 1991. Other indications abound. Hindi is not even in the table though the language boasts more than twice as many speakers as German, French or Japanese, all of which are present. Not obvious from the table but clear in the UNESCO figures, some small languages such as Swedish and Czech are also extraordinarily important relative to their size.

Table 1 sets the background. To probe further into the relevance of the theory, we must relate the figures to translations. With respect to translations, the UNESCO series have become particularly bare since 1987, when a general deterioration of the data began. For 1960 through 1987, I have compiled Table 2 predominantly from the UNESCO annual reports. The first row, which concerns the ratio of translations to total titles, shows a decline from 9 to 7 percent for the world as a whole during this time. The second row indicates that roughly half of all translations fall under the classification of "general literature." As pointed out before, UNESCO never provided a world aggregate for translations of "general literature." However, a check of the major publishing countries for a large number of years shows that the percentage of literature to total titles stands in the 0.15 to 0.30 range. The middle rows of Table 1 concerning the seven major languages say the same. Thus, for the 1960-87 period on average, translations represent 13 to 27 percent of titles in the "general literature" classification $(0.08$ times 0.5 times 100/30, at one extreme; 0.08 times 0.5 times 100/15, at the other). The moderate size of this figure should be stressed. It supports my previous emphasis on the "homecourt" advantage of a separate language. Among the major publishing countries in the world,

\footnotetext{
15 For a broader treatment of the decline of the Russian language that took place at that time, see Kreindler (1993).

16 See Crystal (1999, pp. 289 and 360).
} 
the percentages of translations to titles in the "general literature" classification also predictably tend to be higher in smaller countries with a large reading public than the bigger ones: for example, in the Netherlands, Denmark, and former Czechoslovakia than in Spain or Italy. However, with few exceptions, Sweden being an outstanding one, even in the small-language communities well over half - indeed closer to two-thirds - of published titles of "general literature" originally appear in the home tongue.

The share of English in the world market as a whole has fallen off since the early postwar period when it was particularly high. In fact, the dominance of English in publishing is rather smaller in Table 1 than could be expected from other social observations. Nevertheless, Table 2 confirms the earlier theoretical proposition that the leading language would tend to be disproportionately important in the field of translations. Row 3 of Table 2 shows that while the share of English in the market for fiction was still around 21 percent in 1971 (Table 1), its share of translations of literature was already over 40 percent. When the relative size of the language then fell to below 20 percent of the market by 1991, its share in translations of literature rose to over 50 percent. According to the earlier theoretical analysis, this rise in the percentage of translations in the face of a moderate fall in market share could be explained by technological advances in publishing, transport and telecommunications and associated reductions in distribution costs in the seventies and eighties.

Rows 4 through 7 of Table 2 confirm the resulting theoretical implications for translations into English. These next few rows include information from a variety of other sources besides UNESCO for the years since the mid-eighties (see the notes). The rows display ratios of translations to titles of only 2 to 4 percent both for the UK and the US (rows 4 and 6). In regard to the "general literature" classification as such, the ratios are a bit higher, at least in the UK, that is, 4 to 5 percent since the mid-seventies. I have no separate statistical information about the literature classification for the US since 1980, but according to informed sources (see Colas 1992 and Dalley 1995, for example), the corresponding US figures are not higher. The US ratio of translations to titles in literature used to be twice as high as the UK's in the sixties and seventies. However small all of these figures may seem, equation (7) shows them to accord with general principles given the extraordinarily high ratios of translations of 
English into other tongues. ${ }^{17}$

Nonetheless, translations into the other major European languages happen to be considerable by general world standards, and as a result, those into English remain stunningly low in the comparison. Table 3 derives from a study that was financed by the Commission of the European Communities (BIPE conseil 1993). The statistics are only partial, as they relate to one particular year, 1991. They also focus strictly on translations into the home language and, therefore, fail to reflect the (small) extent to which some European countries outside of the UK translate their own authors into English. (Corresponding translations of English authors into non-English languages are negligible in the UK.) However, the general impression the statistics convey is confirmed by a variety of other sources, including a study by the research department of the French Ministry of Culture (1990), a related and broader investigation by Heilbron (1992) (giving special, though not exclusive, attention to the Netherlands), and a close check of UNESCO data. The first three columns display the much greater importance of translations into the home language elsewhere in Europe than in the UK: the difference is on the order of 8 to one! As can be seen from the data, even a country as small as Portugal translates more French and German into the national tongue than the UK. ${ }^{18}$ Note also the aforementioned tendency for a higher ratio of translations in the smaller countries with large read-

${ }^{17}$ Indeed those ratios are larger than might have been expected from equation (7). If half of the world's translations consist of works originally published in English, then had the other half been translated into English roughly in proportion to the relative size of English in the world market (say, 20 percent), the equation would have led us to expect translations of nonEnglish works into English to be around 0.7 of one percent of total English titles ( 0.5 times 0.07 times 0.2). In fact, the number is higher: between 2 and 3 percent. In the case of "general literature," where translations may represent as much as 30 percent of world titles (rather than only 7) the percentage of translations into English might then have been expected to be around 3 percent of English titles ( 0.5 times 0.3 times 0.2 ). Once again, the actual figure is higher; it is closer to 4 (even 5) percent. These figures also understate translations into English somewhat since they fail to take into account such translations outside of the US and the UK, but these translations are small (countries predominantly translate into their own tongue). Accordingly, while a number of European countries subsidize translations of home literature into English, most of these subsidies go to British publishers and therefore enter into the previous statistics (see Barrett-Ducrocq, ed., 1992, especially Colas).

18 Of course, Portugal may be an entrepot for the Portuguese-speaking world and therefore not so small, but the contrast with the UK is still striking. Compare a more recent study by Heilbron (1999). 
ing publics than the larger ones. ${ }^{19}$

(b) The audiovisual sector

Much of the supply of fiction comes through film and television. In fact, in the area of audiovisual entertainment, the dominance of English is much greater than in books. There the dominance also pertains specifically to the US. Like Canada, Australia and the rest, the UK is not that important. To begin with cinema, the number of films corresponds closely to titles, my chosen measure in the previous discussion. On this measure, US dominance is not even evident. India alone often produces more than twice as many films as the US in recent years. China, Japan, Brazil and others are also important. The dominance of the US in the market clearly emerges only when we measure by theater attendance and especially market value. For many years now, almost all of the ten or twenty best-selling films in export trade are USmade. As compared with differences regarding individual books, differences in investment in individual films are also enormous. In regard to television, the dominance of the US in the programming of fiction in the medium is smaller than for the cinema. Studies of audience ratings in Europe and elsewhere show more prime-time viewing of home-language than American-made fiction, even though the local programs are produced on much lower budgets and are technically inferior in many regards. ${ }^{20}$ All the same, the US dominates world trade in television programs too, if not as much as films. The share of the US in the export of television programs far outstrips that of any other nation while the country imports little of its television programming. These facts are not at issue: ${ }^{21}$ the question is the application of the previous analysis. To what extent does the analysis explain English dominance of world cinema and television as well as publishing? Do the same welfare issues arise?

${ }^{19}$ Except for Belgium, where the publishing industry holds an extraordinary place in the field of children's books and cartoons (Tintin, etc.). The Belgian publishers in the field also notably prefer translating themselves rather than selling the rights (which may have something to do with the combination of words and images).

${ }^{20}$ See Biltereyst (1991, 1992), Hoskins and Mirus (1988), Tracey (1985), Grin and HennisPierre (1997). To quote a "schools brief" on globalisation in mass communications in The Economist (1997): "Look at the top-rated shows in almost any country, and most or all will be local products. Audiences watch imports only as a second choice - and American television channels increasingly repackage their shows when they take them abroad to give them a local presenter and a local feel"' (p. 92).

${ }^{21}$ See Hoskins et al. (1997, 2004), Varis (1984) and IDATE (recent years). 
There are a number of respects in which the earlier analysis extends to the audiovisual sphere. First, in the case of audiovisual entertainment, separate languages set up market barriers to sales. In fact, translation is a greater barrier in audiovisual entertainment than books since it mars enjoyment directly. A reader may even be totally unaware of reading a translation, but a viewer can hardly forget and must accustom himself to the handicap. Either dubbing or sub-titling diminishes enjoyment for most people except possibly when facing subtitles in a spoken language that the person understands. ${ }^{22}$ Second, so far as popularity and sales revenues at home provide a criterion of selection of products for potential dubbing and sub-titling for foreign distribution, the US also probably bears an advantage by virtue of the size of its home-language audience in terms of sales. Third, the advances in the technology of diffusion in recent decades have virtually broken down all market or non-governmental barriers except for cultural ones, including prominently language. These advances have also been far greater than in publishing: witness home video, broadcasting by satellite, and largely stillto-come, internet television. The breakthroughs could then favor English products for dubbing or sub-titling and the US in particular, since the economies of scale could depend on the size of the initial investment (compare Hoskins et al. 1989 and Noam 2001). Yet upon close examination, the application of the previous analysis of the dominance of English faces grave problems, which are particularly severe for the cinema.

As regards the cinema, a film clearly need not succeed in the home market before being made available to foreign-language cinema audiences. US film-makers often depend on the foreign gate from the very start. Many films open simultaneously abroad and at home, and some domestic flops are foreign hits. In addition, Hollywood achieved an important place in the cinema in the era of the silent film, and its success on the world market therefore cannot be simply attributed to the size of the English-language market. The dominance of the American film industry must have something to do with its ability to overcome the handicap of dubbing and sub-titling by offering more popular visual entertainment. In sum, the argument fares

22 With respect to audiovisual products, even spoken accents distinctly make a difference. British English is known to be sometimes dubbed on television in the US, as is Castilian Spanish in Latin America. 
poorly with respect to films.

The situation differs for television in some regards. US television series are indeed essentially produced for domestic consumption and only travel abroad when successful at home. Still, the earlier market analysis of publishing falls short for television too since it emphasizes the size of the public that can be reached in the home language (without dubbing or sub-titles) and the intensity of competition in this language worldwide. Judged by size of audience and hours of watching time alone, the US lead over other countries is not particularly marked. It does not compare with the lead of English over other languages in Table 1. The most populous nations on earth that are not English-speaking produce lots of television entertainment. China (with a significant contribution from Hong Kong), India, Brazil, Mexico, Russia and Japan are all big in the production of entertainment for television. Moreover, this is increasingly so. With rising per capita income, the sizes of national television audiences seem to follow demography more and more (see Berwanger 1987 and Hoskins and McFadyen 1991). The earlier market analysis thus cannot explain the pronounced US dominance in world trade in television programming. ${ }^{23}$

As regards welfare, the application of the previous analysis to television programming fares even worse. The only welfare issue here is the output of enduring products that will continue to yield pleasures for generations to come. Variety of linguistic sources only enters because the diversity enhances the value of the relevant capital that people inherit from the past. Judged on this basis, there is scope for the earlier welfare analysis in the case of the cinema. Some films (the "classics") survive; however, almost no fiction aimed at television does. Essentially the only programs made for television with any shelf life consist of documentaries, whose value, by definition, cannot depend on the original linguistic medium. ${ }^{24}$

In sum, despite some interesting possible extensions of the previous analysis to the

${ }^{23}$ One important factor at work in television broadcasting that probably does not affect publishing much (except through public libraries perhaps) is non-rivalry in consumption.

${ }^{24}$ Of course, US dominance in television broadcasting may have other welfare implications. Quite specifically, some observers claim that US dominance in world television undermines national cultures elsewhere. Others retort that these claims are often a screen for the protectionism in the audiovisual sphere (going back to the 1947 GATT in the case of films). I wish to steer clear of this debate. 
audiovisual sphere, the gaps are wide. The analysis was designed for publishing, or a market where acting, photography and sound effects do not enter. In the subsequent discussion, I will focus exclusively on the written word.

\section{The Evidence about Literature}

(a) The importance of translation and the damaging effect of language dominance on the supply of literary talent

Remarkably few people have ever made contributions to world literature in more than one language. Beckett and Nabokov may be the only two prominent examples. Conrad, who is sometimes mentioned in this connection, is a false illustration in a glaring regard, since he never wrote in his native Polish. Quite conspicuously, expatriate authors generally continue to write in their native language even after living for decades away from home. This holds not only for poets, such as Mickiewicz and Milosz, which may not be surprising, but also for novelists. Mann went on composing in German during a long spell in the US. Though established in France for many years and frequently publishing essays in French, Kundera has only recently ventured to write novels in French rather than Czech. Brodsky also produced a moderate volume of poetry in English in relation to his large Russian output. In her discussion of expatriate authors, Beaujour (1989) mentions a number of writers who engaged in a fairly steady flow of creative writing in two tongues (e.g., Triolet, J. Green), but her sample is modest, and Beckett and Nabokov are her only examples of unquestionable international stature. ${ }^{25}$ Quite generally, the list of authors who have inscribed their names in the history of literature in more than one language since the beginning of time is astonishingly short.

Interestingly enough, many authors, of course, grow up in a multilingual environment. In numerous examples, they receive their basic schooling in a language different from the one they use at home. There must be a time when a choice still exists about employing one language or another for creative writing. Evidently the issue does not always pose itself at a con-

\footnotetext{
${ }^{25}$ Nabokov wrote of his emotional pains in his early efforts to switch from Russian to English (see Beaujour, who brings the material together). As regards Beckett, Beaujour's appendix is enlightening.
} 
scious level. It is not clear that Ionesco ever hesitated about using French as opposed to Rumanian or Kafka about adopting German rather than Czech. However, there are counterexamples; for authors from formerly colonized parts of the world, choosing the language of the former overlord rather than the native tongue (or one of them) may even entail a serious moral dilemma. There is a literature on the subject (see de Swaan 1995). But once a choice of language for creative writing has been made, it seems to be irrevocable. Notwithstanding Beaujour's interesting examples, authors generally marry themselves to a language the way a professional musician does to an instrument. After the clarinette has been adopted, the oboe can no longer be played with the same proficiency. Once the muse has visited an author once, she will refuse to whisper to him again in a different tongue.

The issue of motivation and investment in personal skills is also critical. According to the preceding market analysis, a very gifted person writing in a minor language is likely to have a better chance of publication than one writing in a major one but will necessarily have a much smaller chance of translation and international recognition. If we accept the analogy to science, where a similar situation holds, the result will be to give the writer a smaller incentive to make the required investment for a possible contribution to literature. To expand the analogy, the natural or social scientist of outstanding ability whose preferred language is other than English can generally publish readily in his own language, even in the most prestigious journal in the field but will have much greater difficulty doing so in a similarly ranked journal in English. Yet publishing in English will earn him far more recognition. The result is clear; those who strive to make a mark in their discipline try to publish in English. By and large, the ones who stick strictly to their home language (English excepted, of course) have lower ambitions and do less significant work.

Obviously, the capacity of the natural and social scientist to turn to English is essential. The scientist can do so precisely because communication rather than literary expression is critical in the scientific use of language. The situation differs on this very point in literature. ${ }^{26}$

\footnotetext{
${ }^{26}$ Whether the situation in philosophy, history and the humanities resembles the one described in science or literature is a big issue, which spills over into social science as well. Yet nobody would contest that economics along with mathematics and physics is perfectly translatable
} 
As argued, there the gifted, even the supremely gifted, generally cannot turn to English by mere dint of effort and will-power. Consequently, budding talents evidently will make a greater investment in their writing skills in languages other than English. Notwithstanding, non-English writers will find it much easier to publish than their counterparts of equal native talent who write in English. In addition, their reading public, being more confined and possibly more inclined to see merit in those who express themselves in the home tongue, will probably be less exacting. According to the evidence from the natural and social sciences, those circumstances sap the incentive to invest in personal skills and to shoot for excellence. This evidence would show that a situation where local fame and attention comes readily, whereas international recognition is almost beyond reach, does positive harm to the supply of enduring work. Both the difficulty of switching to English and the greater relative ease of success in home languages other than English will tend to drain the world's pool of literary talent.

(b) Attenuating factors

Two major attenuating forces exist, but how important are they? First, a number of non-English languages possess rich literary traditions of their own and still occupy significant shares of the publishing market. As indicated before, staggering as it is, the dominance of English in publishing is much smaller in terms of market value than in film and television. To some extent, this difference in publishing probably reflects the reading public's stronger concern with language than the audiovisual one's. The difference likely also owes a lot to the tendency of readers with strong literary interests to assimilate at least some foreign literature in the original. This last tendency among English readers may help to understand the extraordinarily low figures for translation into English that we saw before. Thus, for the foreseeable future at least, authors writing in some of the non-English languages (though not necessarily the Asiatic ones) will still be able to count on a sizeable foreign-language audience.

It is nevertheless of note how few of the past greats of world literature writing in anything other than English ever built their reputation independently of translation. Racine is

into English, whereas the foreign-language classics of literature are not. I wish to pitch my tent on the clarity of this distinction. 
probably a good example, ${ }^{27}$ but then he belongs to a period when French was the dominant language. ${ }^{28}$ Other convincing examples (especially outside of French) are surprisingly difficult to find. Even a poet of the current stature of Pushkin only gained his international reputation with considerable delay almost surely because of the problem of translation. ${ }^{29}$

The second factor attenuating the harm done by concentration of world attention (through translation) on a very narrow set of languages in imaginative writing is the adoption of the major languages by offshore writers with distinct cultural experiences and writing programs of their own. The contributions to English literature of the Irish, from Joyce and Yeats on down, are well known. The contemporary examples are even more geographically farflung: Walcott and Naipaul come from the West Indies, Rushdie from India. While the empire is gone, the sun never sets on the English language. Similarly, four of the ten Prix Goncourt in French in one recent ten-year spell went to authors from the Caribbean, North Africa, Lebanon, and to a naturalized Russian. The importance of Latin American contributions to Spanish in this century cannot go unmentioned. The breadth of cultural infusion that results obviously reduces some of the damaging effects of language dominance.

\section{Discussion and Conclusion}

I have argued that the dominance of English threatens the accumulation of capital in the form of literature. Since publishers need to offset the costs of translation, they tend to confine translations to works that have sold especially well in the original language and thereby to

${ }^{27}$ In his inaugural lecture after assuming the chair in comparative literature at Oxford University in 1994, Steiner (1995) makes a point of the much greater accessibility of Shakespeare than Racine through translation.

28 The height of French supremacy in letters and diplomacy is usually taken to be the seventeenth century, but Nabokov (1959) recounts that Russian writers still tended to read the English classics in French in the early nineteenth century. See Heilbron (1992).

${ }^{29}$ With respect to Pushkin, Flaubert wrote to Turgenev: "il est plat, votre poète" [he is flat, your poet] (Mirsky 1963, p.239), rather indicative of the general problem of translation. Of course, Nabokov also had many unkind words to say for the early translators of Pushkin (the later ones too), but then Nabokov's standards were pitched rather high: nothing fits his general mood on the subject of translation better than the Italian "Traduttore, traditore" [translator, traitor] (Nabokov 1975, preface, vol. I, and commentary, vol. II). 
limit their costs of selection. Because of some economies of scale and the signaling value of success in a huge market, the dominant language will capture a disproportionate share of translations. Very significantly too, according to the market analysis, advances in the technology of diffusion increase the advantage of the dominant language in the field of translations.

The broad facts agree with the theory. Since the sixties, if anything, the place of English in the world publishing industry has gone down, not up. In a development that falls outside the model and probably reflects the increase in literacy and standards of living in the world, the market share of English in the overall publishing market, including the section covering "general literature," has declined in the last 30 years or more. English has also not gained on the next two or three major languages (which have shifted) in publishing of fiction in the world. Moreover, the evidence shows language to be a formidable protection for authors, since even in small-language communities, translations mostly constitute less than half of total works of fiction and usually closer to a fifth. Yet, in accordance with the model, the largest language in the market, English, does indeed carry a highly disproportionate share of translations. Most telling of all, the dominance of English in translations has actually risen in the last three or four decades despite the fall in the language's share of the market as a whole. Concomitantly, translations into English have remained as low as before. The analysis ascribes these events to the influence of improvements in communications and reductions in distribution costs, together with the importance of large sales in a major language.

Translations obviously matter since virtually all imaginative works that endure are translated. Moreover, translations are essential to reach a world audience. The need to write in English in order to reach a world audience affects incentives and diminishes the pool of talent that is capable of contributing to world literature. In addition, diversity of language sources enriches literary capital as such. Thus, the welfare issue seems clear.

Two problematic facts should be mentioned in closing. When the printing press arose in the fifteenth century, it encouraged original writing in the vernaculars. Yet according to the present argument, greater ease of communication encourages the concentration of translation from a single language. I cannot do justice to this large and interesting topic here, but a basic factor is likely to be that there was no dominant world language in the fifteenth century. Latin 
may have held such a position in Europe in some respects, but even in this part of the world the language was not the tongue of everyday speech in any important political domain. Its lack of a veritable political and economic base probably underlies the fact that the printing press hastened its decline rather than the opposite. By contrast, we are now in a world where the major language of international discourse, English, has a solid cultural and political base in the largest economic power on earth, the US, and its progenitive nation-state, the UK. Though demanding expert attention, the discrepancy may therefore be easy to resolve.

Next, it is also difficult to overlook the fact that while many specialists in the field of literature recognize the unprecedented place of English in the world today, they do not necessarily share my concern. In the recent edition of After Babel (1992), Steiner repeats his earlier assessment in the 1975 first edition: "Like no other tongue before it, English has expanded into a world-language" (1992, p. 492). However, his only expressed disquiet on the subject remains, as in the first edition, the possible adverse effect on English itself coming from an enlarged use of the language as an impoverished go-between. Underlying this attitude of calm may be some sense, which is probably widely shared by other literary specialists, that the supply of great literature in different languages than English is utterly unpredictable and depends on the emergence of writing genius with an irrepressible need to express itself. For this reason, let me voice one last time the grounds for greater concern.

Literature must meet a market test since an author must find a publisher. Meeting the test alone, however, will not assure any production of literature even by people with the right endowments. Gifted individuals must also have the proper motivation and make the right investment in their own skills. If those people are constituted like others with a similar need to invest heavily in their own skills before they can make a contribution to their discipline, then circumstances where they cannot hope to reach a world audience in their own language will discourage them from shooting high enough and making the necessary effort. Evidently, other factors may intervene. Who can say whether a spurt of regionalism in Catalonia will not incite a major literature in Catalan, just as a certain Volkgeist spurred a number of literatures in the past? Nonetheless, there is reason to fear that the dominance of English in translations will limit the output of literature by offering most of the world's outstanding literary talents the 
wrong incentives: too much facility of publication in the home language combined with too little hope of reaching foreign-language readers. Literary output might then become just one more field where the best work is done in English. If so, the production of imaginative prose and poetry in other languages may well be relegated to the same provincial status that such writing has already acquired in many areas of intellectual activity. It is my contention that we cannot really view this prospect with indifference. 


\section{$\underline{\text { References Cited }}$}

- Allan, W., Curwen, P., 1990. Competition and Choice in the Publishing Industry. London: Institute of Economic Affairs.

- Barrett-Ducrocq, F. (Ed.), 1992. Traduire l'Europe. Paris: éd. Payot.

- Baumol, H., Baumol, W.,1984. The mass media and the cost disease. In: Hendon, W., Shaw, D., Grant, N. (Eds.). Economics of Cultural Industries, Akron, Ohio: Association for Cultural Economics, 109-23.

- Baumol, W., Bowen, W., 1966. Performing Arts - The Economic Dilemma. New York: Twentieth Century Fund.

- Beaujour, E., 1989. Alien Tongues. Ithaca: Cornell University Press.

- Berwanger, D., 1987. Television in the Third World: New Technology and Social Change. Bonn: Friedrich-Ebert-Stiftung.

- Biltereyst, D., 1991. Resisting American hegemony: a comparative analysis of the reception of domestic and U.S. fiction. European Journal of Communication 6, 469-97.

- Biltereyst, D., 1992. Language and culture as ultimate barriers? An analysis of the circulation, consumption and popularity of fiction in small European countries. European Journal of Communication 7, 517-40.

- BIPE [Bureau d'information de la prévision économique] conseil, 1993. Approche statistique de la traduction littéraire en Europe. Nov., mimeo.

- Breton, A., 1999. The cultural yield on languages and linguistic assimilation. In: Breton, A. (Ed.). Exploring the Economics of Language. Ottawa: Canadian Heritage, 89-115.

- Bookseller, The. London, weekly (various issues).

- Colas, D. 1992. Les problèmes d'aide. In: Barrett-Ducrocq, F. (Ed.), 97-123.

- Crystal, D., 1997. English as a Global Language. Cambridge, UK: Cambridge University Press.

- Crystal, D., 1999. The Cambridge Encyclopedia of Language. Cambridge, UK: Cambridge University Press, 2d. edition.

- Curwen, P., 1986. The World Book Industry. London: Euromonitor Pub. Co.

- Dalley, J., 1995. A closed circle? Times Literary Supplement, Dec. 1, 25. 
- Dalmazzone, S., 1999. Economics of language: a network externalities approach. In: Albert Breton (Ed.). Exploring the Economics of Language. Ottawa: Canadian Heritage, 63-87.

- Dixit, A., Stiglitz, J., 1977. Monopolistic competition and optimum product diversity. American Economic Review 67, 297-308.

- Economist, The, 1997. Schools brief: a world view. Nov.29-Dec.5, 91-92.

- Ganne, V., Minon, M., 1992. Géographie de la traduction. In: Barrett-Ducrocq, F. (Ed.), 6595.

- Grin, F., 1996. The economics of language: survey, assessment and prospects. International Journal of the Sociology of Language 121, 17-44.

- Grin, F., Hennis-Pierre, C., 1997. La diversité linguistique et culturelle face aux règles du commerce international: le cas du film et des émissions de télévision. In: Abou, S., Haddad, K. (Eds.) La diversité linguistique et culturelle et les enjeux du développement. Beyrouth: Université Saint-Joseph, 265-286.

- Hagège, Claude, 1994. Le souffle de la langue. Paris: Odile Jacob, 2 d ed.

- Heilbron, J., 1992. Nederlandse vertalingen wereldwijd. In: Heilbron, J. de Nooy, W., Tichelaar, W. (Eds.). Warin een klein land: Nederlandse cultuur in international verband, 207-52, available to me mostly through a French communication to a colloquium in 1994: "Traduction et communications européennes," mimeo.

- Heilbron, J., 1999. Towards a sociology of translation: book translations as a cultural worldsystem. European Journal of Social Theory 2, 429-444.

- Hoskins, C., McFadyen, S., 1991. The U.S. competitive advantage in the global television market: is it sustainable in the new broadcasting environment? Canadian Journal of Communication 16, 207-224.

- Hoskins, C. McFadyen, S., Finn, A., 1997. Global Television and Film. Oxford: Oxford University Press.

- Hoskins, C. McFadyen, S., Finn, A., 2004. Media Economics. London: Sage Publications.

- Hoskins, C., Mirus, R., 1988. Reasons for the US dominance of the international trade in television programmes. Media, Culture and Society 10, 499-515.

- Hoskins, C., Mirus, R., Rozeboom, W., 1989. U.S. television programs in the international 
market: unfair pricing? Journal of Communication 39, 55-75.

- Hotelling, H., 1929. Stability in competition. Economic Journal 39, 41-57.

- IDATE [Institut de l'audiovisuel et des télécommunications en Europe]. The World Film and Television Market, annual (various years).

- Imrie, M., 1992. Verso: la politique de traduction d'un éditeur britannique. In: BarrettDucrocq, F. (Ed.), 129-33.

- Kreindler, I., 1993. A second missed opportunity: Russian in retreat as a global language. International Political Science Review 14, 257-74.

- McCrum, R., Cran, W., MacNeil, R. 1992. The story of English. London and Boston: Faber and Faber, 2d ed.

- Ministère de la Culture (France), 1990. Préliminaires pour une statistique de l'édition en Europe. Département des études et de la prospective, mimeo.

- Mirsky, D. 1963. Pushkin, New York: E.P. Dutton \& Co.

- Nabokov, V. 1959. The servile path. In: Brower, R. (Ed.). On Translation. Cambridge, Mass.: Harvard University Press, 97-110.

- Nabokov, V., 1975. Author's translation of Aleksandr Pushkin, Eugene Onegin, in 2 volumes, revised ed., Princeton: Princeton Univ. Press.

- Noam, E., 2001. Will Internet-TV be American? Columbia University, mimeo.

- Publishers Weekly. New York, various issues.

- Rosen, S., 1981. The economics of superstars. American Economic Review 71, 845-58.

- Salop, S., 1979. Monopolistic competition with outside goods. Bell Journal of Economics $10,141-56$.

- Sauvaget, B., 1987. 1986: une bonne année pour l'édition aux Etats-Unis. Livres Hebdo 51, 14 Dec., 59.

- Steiner, G., 1992. After Babel. Oxford: Oxford Univ. Press, 2d ed.

- Steiner, G., 1993. From Caxton to Omeros: the continuing appeal of Homer to Anglo-Saxon ideals and experience. Times Literary Supplement. Aug. 27, 13-16.

- Steiner, G., 1995. Qu'est-ce la littérature comparée? Commentaire 70, Summer, 383-93, translated by Louis Evrard. 
- de Swaan, A., 1993. The evolving European language system: a theory of communication potential and language competition. International Political Science Review 14, 241-55.

- de Swaan, A., 1995. Unequal relations between language groups." Amsterdam School for Social Science Research, Aug., mimeo.

- Tracey, M., 1985. The poisoned chalice? International television and the idea of dominance. Daedalus 114, Fall, 17-56.

- UNESCO. Statistical Yearbook. Paris: UNESCO, various issues.

- Varis, T. 1984. The international flow of television programs. Journal of Communication 34, $143-52$. 
TABLE 1

SHARES OF THE SEVEN MAJOR LANGUAGES IN THE BOOK MARKET

\begin{tabular}{|l|c|c|c|c|c|c|c|}
\hline & English & Chinese & German & Spanish & French & Russian & Japanese \\
\cline { 2 - 8 } & $\mathbf{T}(\mathbf{E}) / \mathbf{T}$ & $\mathbf{T}(\mathbf{C}) / \mathbf{T}$ & $\mathbf{T}(\mathbf{G}) / \mathbf{T}$ & $\mathbf{T}(\mathbf{S}) / \mathbf{T}$ & $\mathbf{T}(\mathbf{F}) / \mathbf{T}$ & $\mathbf{T}(\mathbf{R}) / \mathbf{T}$ & $\mathbf{T}(\mathbf{J}) / \mathbf{T}$ \\
$\mathbf{1 9 7 1}$ & 0.24 & - & 0.10 & 0.06 & 0.05 & 0.12 & 0.06 \\
$\mathbf{1 9 8 1}$ & 0.21 & 0.03 & 0.09 & 0.09 & 0.07 & 0.09 & 0.06 \\
$\mathbf{1 9 9 1}$ & 0.20 & 0.09 & 0.08 & 0.07 & 0.06 & 0.04 & 0.04 \\
$\mathbf{1 9 7 1}$ & $\mathbf{T L}(\mathbf{E}) / \mathbf{T}(\mathbf{E})$ & $\mathbf{T L}(\mathbf{C}) / \mathbf{T}(\mathbf{C})$ & $\mathbf{T L}(\mathbf{G}) / \mathbf{T}(\mathbf{G})$ & $\mathbf{T L}(\mathbf{S}) / \mathbf{T}(\mathbf{S})$ & $\mathbf{T L}(\mathbf{F}) / \mathbf{T}(\mathbf{F})$ & $\mathbf{T L}(\mathbf{R}) / \mathbf{T}(\mathbf{R})$ & $\mathbf{T L}(\mathbf{J}) / \mathbf{T}(\mathbf{J})$ \\
$\mathbf{1 9 8 1}$ & 0.15 & - & 0.17 & 0.30 & 0.23 & 0.11 & 0.23 \\
$\mathbf{1 9 9 1}$ & 0.20 & 0.19 & 0.22 & 0.24 & 0.22 & 0.15 & 0.32 \\
& $\mathbf{T L}(\mathbf{E}) / \mathbf{T L}$ & $\mathbf{T L}(\mathbf{C}) / \mathbf{T L}$ & $\mathbf{T L}(\mathbf{G}) / \mathbf{T L}$ & $\mathbf{T L}(\mathbf{S}) / \mathbf{T L}$ & $\mathbf{T L}(\mathbf{F}) / \mathbf{T L}$ & $\mathbf{T L}(\mathbf{R}) / \mathbf{T L}$ & $\mathbf{T}(\mathbf{J}) / \mathbf{T L}$ \\
$\mathbf{1 9 7 1}$ & 0.21 & - & 0.10 & 0.10 & 0.07 & 0.08 & 0.08 \\
$\mathbf{1 9 8 1}$ & 0.19 & 0.03 & 0.09 & 0.10 & 0.06 & 0.08 & 0.09 \\
$\mathbf{1 9 9 1}$ & 0.19 & 0.11 & 0.07 & 0.08 & 0.07 & 0.04 & 0.05 \\
\hline
\end{tabular}

$\mathrm{T}(\mathrm{E}) / \mathrm{T}=$ ratio of titles in English to total titles; $\mathrm{TL}(\mathrm{E}) / \mathrm{T}(\mathrm{E})=$ ratio of titles of general literature in English to total titles in English; TL(E)/TL = ratio of titles of general literature in English to total titles of general literature.

SOURCE: UNESCO, Statistical Yearbook, various issues (with supplementary information about English publications by the US and the UK based on sources mentioned in the notes to Table 2). For $\mathrm{T}(\mathrm{Y}) / \mathrm{T}$, where language $\mathrm{Y}=\mathrm{E}, \mathrm{C}, \mathrm{G}, \mathrm{S}, \mathrm{F}, \mathrm{R}$ or $\mathrm{J}$, the central source is the table for book production by language of publication. The table breaks up production of titles by country between works in the home language, in foreign languages E, F, G, S, R (where these are foreign), and others. To clarify, in the case of Canada, where $\mathrm{E}$ and $\mathrm{F}$ are both home languages, the notes to the table would show how much of production in the home language is in $\mathrm{E}$ and how much in F. In order to calculate $\mathrm{T}(\mathrm{Y})$, the basic principle is to sum up home production in $\mathrm{Y}$ in the $\mathrm{Y}$-speaking countries (using the notes as necessary) and to add the production in $\mathrm{Y}$ by the non-Y speaking ones. However, numerous interpolations and estimates were necessary to cover gaps for missing countries for relevant years. In these cases, the separate information for translations elsewhere in the Statistical Yearbook often served to infer the production of titles in the home language. For TL(Y)/T(Y), the central source is the table for book production by classification of titles by country. 
TABLE 2

TRANSLATIONS IN THE WORLD, THE UK AND THE US

\begin{tabular}{|c|c|c|c|c|c|c|c|}
\hline & $1960-64$ & 1965-69 & $1970-74$ & $1975-79$ & $1980-84$ & 1985-87 & $1988-96$ \\
\hline (1) $\frac{T R}{T}: W$ & 0.09 & 0.08 & 0.08 & 0.08 & 0.07 & 0.07 & \\
\hline (2) $\frac{T R L}{T R}: W$ & 0.53 & 0.49 & 0.48 & 0.46 & 0.50 & 0.50 & \\
\hline (3) $\frac{T R(E)}{T R}: W$ & 0.41 & 0.43 & 0.47 & 0.46 & 0.49 & 0.52 & \\
\hline (4) $\frac{T R}{T}$ : UK & 0.026 & 0.024 & 0.026 & 0.037 & 0.024 & $0.021^{(1)}$ & $0.027^{(2)}$ \\
\hline (5) $\frac{\text { TRL }}{\text { TL }}:$ UK & 0.021 & 0.029 & 0.033 & 0.047 & 0.038 & $0.037^{(\mathbf{1})}$ & $0.047^{(2)}$ \\
\hline (6) $\frac{T R}{T}:$ US & 0.066 & 0.036 & 0.027 & 0.018 & - & $0.030^{(3)}$ & $0.033^{(4)}$ \\
\hline (7) $\frac{T R L}{T L}:$ US & 0.065 & 0.087 & 0.074 & 0.07 & & & \\
\hline
\end{tabular}

$\mathrm{TR} / \mathrm{T}=$ ratio of translations to total titles; TRL/TR $=$ ratio of translations of general literature to total translations; $\mathrm{TR}(\mathrm{E}) / \mathrm{TR}=$ ratio of translations from English into other languages to total translations; TRL/TL = ratio of translations of general literature to total titles of general literature; $\mathrm{W}=$ world.

SOURCE: 1980-87 (except where indicated otherwise further below): UNESCO, Statistical Yearbook, various issues.

(1) For 1985 alone.

(2) 1988 from UNESCO, Statistical Yearbook; 1989 from Allen and Curwen (1991, pp. 4648); 1990 from Ganne and Minon (1992, pp. 64, 70); 1991-96 from various issues of The Bookseller. L or "general literature" always refers to the sum of "fiction," "literature," and "poetry" both in the UNESCO yearbooks and in The Bookseller.

(3) 1985 and 1986 average. From Sauvaget (1987).

(4) Average covering only 1988-91 inclusively. From Publishers Weekly, various issues. 
TABLE 3

TRANSLATIONS IN THE EEC (1991)

\begin{tabular}{|l|c|c|c|c|c|c|c|c|c|c|}
\hline & TR & $\frac{\text { TR }}{\mathbf{T}}$ & $\frac{\text { TRL }}{\text { TL }}$ & $\frac{\text { TR(E) }}{\text { TR }}$ & $\frac{\text { TR(F) }}{\text { TR }}$ & $\frac{\text { TR(G) }}{\text { TR }}$ & $\frac{\text { TR(S) }}{\text { TR }}$ & $\frac{\text { TR(I) }}{\text { TR }}$ & $\frac{\text { TR(SL) }}{\text { TR }}$ & etc. \\
\cline { 2 - 8 } Belgium & 703 & 0.10 & 0.07 & 0.54 & 0.09 & 0.16 & 0.04 & 0.07 & 0.01 & 0.09 \\
Denmark & 2336 & 0.20 & 0.76 & 0.66 & 0.06 & 0.09 & 0.01 & 0.01 & $\approx 0$ & 0.17 \\
France & 6991 & 0.18 & 0.34 & 0.56 & - & 0.13 & 0.04 & 0.05 & 0.05 & 0.17 \\
Germany & 9557 & 0.14 & 0.34 & 0.66 & 0.12 & - & 0.12 & 0.04 & 0.04 & 0.02 \\
Greece & 1667 & 0.36 & 0.37 & 0.57 & 0.13 & - & - & - & - & - \\
Ireland & 16 & 0.03 & - & - & 0.44 & 0.12 & - & 0.12 & - & - \\
Italy & 10487 & 0.26 & 0.48 & 0.51 & 0.16 & 0.13 & 0.03 & - & 0.02 & 0.15 \\
Neth'ds & 4287 & 0.27 & 0.58 & 0.69 & 0.07 & 0.16 & 0.01 & 0.02 & $\approx 0$ & 0.07 \\
Portugal & 2806 & 0.44 & - & 0.41 & 0.26 & 0.03 & 0.06 & 0.06 & 0.01 & 0.17 \\
Spain & 10542 & 0.24 & 0.38 & 0.52 & 0.16 & 0.09 & - & 0.07 & 0.02 & 0.14 \\
UK & 1689 & 0.03 & 0.04 & - & 0.26 & 0.02 & 0.06 & 0.07 & 0.08 & 0.51 \\
EC & & 0.17 & 0.32 & 0.6 & 0.14 & 0.10 & 0.03 & 0.04 & - & 0.09 \\
\hline
\end{tabular}

$\operatorname{TR}(E)=$ Translations from English within the country in question; TR $(F)=$ Translations from French instead; TR(G) from German; TR(S) from Spanish; TR(I) from Italian; TR(SL) from a Slavic language; etc.: all the rest.

SOURCE: BIPE conseil (1993). The same source presents a TR/T ratio of 0.61 for Sweden in 1991. 